\title{
FARMERS' LIVELIHOODS STRATEGY BASED ON ASSET IN PANDANSARI VILLAGE POST ERUPTION OF MOUNT KELUD
}

\author{
Abraham R. Illu ${ }^{1 *}$, Abdul Wahib Muhaimin², Budi Setiawan² \\ ${ }^{1}$ Post Graduate Program, Faculty of Agriculture, University of Brawijaya, Indonesia) \\ ${ }^{2}$ Faculty of Agriculture, University of Brawijaya, Indonesia \\ *corresponding author: abrahamillu2@gmail.com
}

\begin{abstract}
This study examines farmers' livelihood strategies based on livelihood assets in Pandansari Village, Ngantang District, Malang Regency. This study uses a quantitative descriptive approach using a Likert scale. Primary data were obtained through in-depth interviews using questionnaires and field observations, while secondary data were obtained through literature studies from various related sources. The location was determined purposively with the consideration that Pandansari Village was the area in Ngantang District that was the worst affected by the eruption of Mount Kelud. Seventy-five farmers with simple random sampling technique were selected as respondents in this study. The respondents' livelihood assets include human capital, natural capital, social capital, financial capital, and physical capital. Meanwhile, livelihood strategies are classified into survival strategies, consolidation strategies and accumulation strategies. The results show that the most vital livelihood asset is social capital, while the indicator for natural capital is the weakest. The strongest indicator of the farmer's livelihood strategy in Pandansari Village is the consolidation strategy.
\end{abstract}

Keywords: Livelihood Strategies, Livelihood Assets, Farmer, Eruption, Kelud.

http://dx.doi.org/10.21776/ub.agrise.2021.021.4.3

Received 19 April 2021

Accepted 11 October 2021

Available online 31 October 2021

\section{INTRODUCTION}

Indonesia, as a country located in the tropics, provides enormous benefits to the agricultural sector. One of the benefits is fertile land availability to support agricultural production activities (Efendi, 2006). Agriculture is a very vital sector for the Indonesian economy. With the potential for the land area spread across thousands of islands, Indonesia is an agricultural country. The agricultural sector is the largest sector that absorbs $27.33 \%$ of the total workforce and contributes $12.90 \%$ to the Gross Domestic Product (GDP) in Indonesia in 2018 (Central Statistics Agency, 2019).

Despite having promising agricultural potential, Indonesia's territory is also a disasterprone area. The National Disaster Management Agency (2014) states that Indonesia has at least 12 disaster threats. One of the natural disasters that have a significant threat in Indonesia is a volcanic eruption. Located in a series of the
Pacific Ring of Fire (Pacific Ring of Fire), Indonesia has 127 active volcanoes, which make it the area with the most active mountains in the world (National Disaster Management Agency, 2016).

Land that is in areas affected by volcanic eruptions has the potential to support agricultural activities. Land conditions around the volcanic area have a high level of soil fertility (Eswaran et al., 1993; Dahlgreen et al., 2004). In line with that, Shoji and Takahashi (2002) state that the volcanic material from the eruption is a material that has a high nutrient content, thus contributing to increasing fertility and soil bearing capacity. An increase in the land's carrying capacity due to the chemical compounds contained in the eruption material.

Rahayu et al. (2014), in their research on the impact of the eruption of Mount Merapi on land and its recovery efforts, revealed that volcanic eruptions have primary and secondary hazards 
and can damage the land. In general, land damage due to eruptions is the loss of some or a lot of germplasm and changes in plant biodiversity, loss of water catchment areas, destruction of forests, and even blocking of water sources, and loss of water channels. Furthermore, the soil's burial and the obstruction of soil formation due to repeated eruptions, loss of access roads to agricultural land and failure of land boundaries by eruptions and cold lava.

Pandansari Village in Ngantang District is one of the villages with a very severe level of damage in the Malang Regency during the eruption of Mount Kelud in 2014. Its position on the slopes and foothills of Mount Kelud has resulted in agricultural land, and yards covered with eruptive material such as ash, sand and rocks with a thickness of $30-50 \mathrm{~cm}$, cropping (plantation, food, horticulture, feed) becomes dry and dies (Agricultural Research and Development Agency - Ministry of Agriculture, 2015). Besides the threat of losing their livelihoods, other impacts of the eruption of Mount Kelud are psychological shocks, loss of property, as well as other vulnerabilities in various aspects.

Based on the background and description above, this research is aimed at examining the effect of livelihood assets on the livelihood strategy in supporting the sustainability of the livelihoods of farmers in Pandansari Village, Ngantang District, Malang Regency after the 2014 eruption of Mount Kelud.

\section{RESEARCH METHODS}

This research is explanatory research that focuses on the causal relationship between the research variables and tests the previously formulated hypotheses (Singarimbun \& Effendi, 2006).

The research location was determined purposively in Pandasari Village, Ngantang District, Malang Regency based on the researchers' considerations. With the simple random sampling method, 75 samples were selected to be respondents in this study. This number has met the rule of the thumb requirements stated by Solimun et al. (2018), namely, the minimum sample size for research is ten times the number of variables.

Data analysis using quantitative descriptive analysis. This combination approach was chosen to understand the phenomenon of implementing the respondent's livelihood strategies in the field. The descriptive pentagon asset analysis uses a Likert scale of 1 to 5 . The Likert scale is used to measure the attitudes, perceptions and opinions of a person or group of people about social phenomena (Sugiyono, 2011). On the Likert scale, there are two statements of attitude, namely statements that are supporting (favourable) and statements that are not supporting (unfordable).

The scoring of each question indicator from each respondent will be accumulated into a total score with the following calculations:

$$
\begin{aligned}
& \mathrm{X}=\begin{array}{l}
\text { lowest Likert score } \mathrm{x} \text { number of } \\
\text { respondents }
\end{array} \\
& \mathrm{Y}=\begin{array}{l}
\text { highest Likert score } \mathrm{x} \text { number of } \\
\text { respondents }
\end{array} \\
& \text { Formula: } \mathrm{T} \times \mathrm{Pn} \\
& \mathrm{T}=\text { Total number of respondents who voted } \\
& \mathrm{Pn}=\text { Choice of Likert score } \\
& \text { Index\% formula = Total Score } / \mathrm{Y} \times 100
\end{aligned}
$$

Furthermore, the interval from the lowest percentage score $(0 \%)$ to the highest score percentage $(100 \%)$ was determined to interpret the total score with the following criteria:

Numbers $0 \%-19.99 \%$ = Very Not Good

Numbers 20\% - 39.99\% = Not Good

Numbers $40 \%-59.99 \%=$ Moderate

Numbers $60 \%-79.99 \%=$ Good

Numbers $80 \%-100 \%=$ Very Good

\section{RESULTS AND DISCUSSION}

\section{Livelihood Assets Pentagon Analysis}

The Livelihood Framework identifies five main asset categories or types of capital on which the livelihoods of a community are built, which are then called pentagon assets. This instrument was developed to enable the visualization of information about community assets that illustrates the relationship between these assets (DFID, 2000).

The asset pentagon is a pentagon diagram depicting the linkages and relationships between livelihood assets owned and controlled by farmers. These assets are human capital, natural capital, social capital, financial capital and physical capital. The closer to the midpoint of the graph, the more vulnerable these livelihood assets are interpreted. Livelihood assets are the basis for determining various livelihood strategy activities 
in achieving welfare. Wijayanto (2019), in his research, states that human capital, natural capital, social capital, financial capital and physical capital have a positive influence on the selection of various livelihood strategies, either directly or indirectly.

Table 1 and Figure 1 below show the calculation of the score index and also the asset pentagon image in the study area, which shows:

Table 1. Classification of Respondents' Livelihood Asset Index

\begin{tabular}{|c|l|c|c|c|}
\hline No & $\begin{array}{c}\text { Liveliho } \\
\text { od Assets }\end{array}$ & $\begin{array}{c}\text { Scor } \\
(1- \\
375)\end{array}$ & $\begin{array}{c}\text { Percent } \\
\text { age } \\
\text { Index } \\
(\%)\end{array}$ & $\begin{array}{c}\text { Index } \\
\text { Interpret } \\
\text { ation }\end{array}$ \\
\hline 1 & $\begin{array}{l}\text { Human } \\
\text { Capital }\end{array}$ & 284,85 & 75,96 & Good \\
\hline 2 & $\begin{array}{l}\text { Natural } \\
\text { Capital }\end{array}$ & 262,5 & 70,00 & Good \\
\hline 3 & $\begin{array}{l}\text { Social } \\
\text { Capital }\end{array}$ & 302,16 & 80,58 & $\begin{array}{c}\text { Very } \\
\text { Good }\end{array}$ \\
\hline 4 & $\begin{array}{l}\text { Financial } \\
\text { Capital }\end{array}$ & 263,11 & 70,02 & Good \\
\hline 5 & $\begin{array}{l}\text { Physic } \\
\text { Capital }\end{array}$ & 293,28 & 78,21 & Good \\
\hline
\end{tabular}

Source: Primary data analyzed, 2020

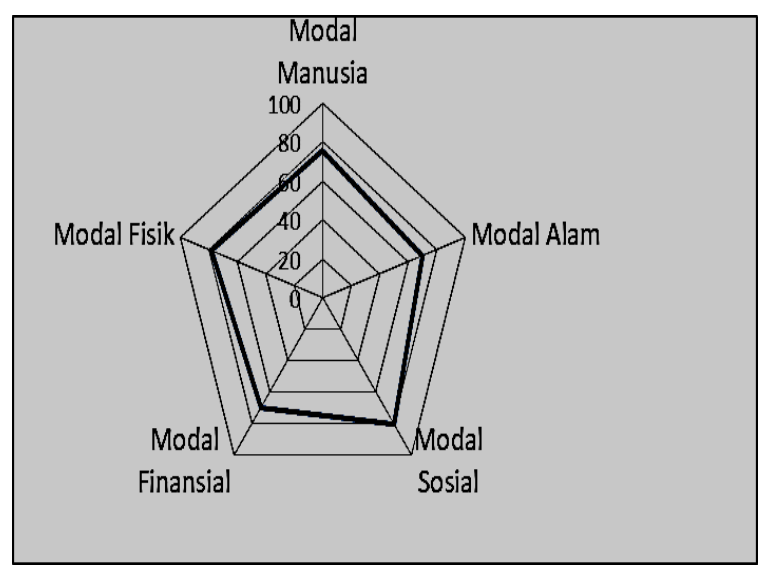

Figure 1. Pentagonal Assets of Responden

\section{a. Human Capital}

Human capital is an asset with particular concern in the context of the livelihood approach because humans are an important central subject as actors and beneficiaries of the livelihood efforts carried out (people centre). DFID (2000) states that talent, experience and health have a relationship with the livelihood strategies being carried out. The results of descriptive analysis of the human capital indicators are described in table 2 below:

Table 2. Human Capital Indicator Score Index

\begin{tabular}{|c|l|c|}
\hline No & \multicolumn{1}{|c|}{ Indicator } & $\begin{array}{c}\text { Score } \\
\operatorname{Index}(\%)\end{array}$ \\
\hline 1 & Farming knowledge & 85,07 \\
\hline 2 & Farming skills & 77,33 \\
\hline 3 & Farming experience & 78,40 \\
\hline 4 & Health & 79,20 \\
\hline 5 & Household member & 73,87 \\
\hline 6 & Other business skills & 69,60 \\
\hline 7 & $\begin{array}{l}\text { Other business } \\
\text { experiences }\end{array}$ & 68,27 \\
\hline \multicolumn{2}{|l|}{ Total average } & 75,96 \\
\hline
\end{tabular}

Source: Primary data analyzed, 2020

The results of table 2 show that the highest indicator score index for human capital is farming knowledge. Farming knowledge is generally obtained by farmers from the inheritance of their parents from generation to generation. Knowledge and skills are also acquired through mentoring and training conducted by the government, thereby creating experiences for respondents. These three indicators are much stronger than the respondents' skills and experience indicators for other activities besides farming.

The farming which is done by the respondent is poly-culture farming with the intercropping system.

\section{b. Natural Capital}

DFID (2000) describes natural capital as a natural stock that provides carrying capacity as well as valuable benefits in human livelihood efforts.

Table 3. Natural Capital Indicator Score Index

\begin{tabular}{|c|l|c|}
\hline No & \multicolumn{1}{|c|}{ Indicator } & $\begin{array}{c}\text { Score } \\
\text { Index }(\%)\end{array}$ \\
\hline 1 & Land Fertility & 67,73 \\
\hline 2 & Irrigation Sources & 54,40 \\
\hline 3 & Climate Suitability & 85,87 \\
\hline 4 & Farm Production & 72,00 \\
\hline \multicolumn{2}{|c|}{ Total average } & 70,00 \\
\hline
\end{tabular}

Source: Primary data analyzed, 2020

Based on table 3 above, climate suitability is the strongest indicator, which is equal to $85.87 \%$. 
Meanwhile, irrigation source is the weakest indicator with $54.40 \%$. This is because most of the agricultural land in the study area is dry land that only relies on rainfall. The second weakest indicator of land fertility is the eruption material in the form of sand and gravel, which still covers the farming land with a thickness of about 5-20 $\mathrm{cm}$, thereby reducing productivity, leading to the respondent's income.

\section{c. Social Capital}

Social capital is a social resource that benefits and are used by the community to obtain their livelihood goals. These social resources are generally intangible but have benefits for the community (DFID, 2000).

Table 4. Social Capital Indicator Score Index

\begin{tabular}{|c|l|c|}
\hline No & \multicolumn{1}{|c|}{ Indicator } & $\begin{array}{c}\text { Score } \\
\text { Index }(\%)\end{array}$ \\
\hline 1 & Organizational & 78,67 \\
\hline 2 & Social Networking & 79,73 \\
\hline 3 & Trust & 81,78 \\
\hline 4 & Mutual cooperation & 89,78 \\
\hline \multicolumn{2}{|c|}{ Total average } & 80,58 \\
\hline
\end{tabular}

Source: Primary data analyzed, 2020

Table 4 above shows that the indicator of social capital is the least vulnerable asset compared to the other four livelihood assets with an average indicator of $80.58 \%$. As a rural community that is still thick with social wealth such as mutual cooperation and trust, it makes existing kinship relationships stronger. The mutual assistance indicator itself is the strongest indicator with a percentage of $89.78 \%$. Meanwhile, the organizational indicator has the lowest percentage, which is $78.67 \%$. This is because not many respondents are involved and actively participate in community organizations such as farmer groups and other organizations. Pospěch \& Spěšná (2011) confirms that social capital has a very important role, social capital, as well as economic capital, can be used as a resource for improving the economic performance of agricultural enterprises. Social capital that is manifested in interaction patterns both vertically and horizontally will create work comfort and foster trust as individuals and institutions, thus giving birth to the strength to improve performance.

\section{d. Financial Capital}

Financial capital is all financial sources that can be utilized and used by the community in achieving a livelihood. Financial capital consists of private reserves or supplies owned by the public as well as those of financial institutions as well as regular flows of funds (DFID, 2000).

Table 5. Financial Capital Indicator Score Index

\begin{tabular}{|c|l|c|}
\hline No & \multicolumn{1}{|c|}{ Indicator } & $\begin{array}{c}\text { Score } \\
\text { Index }(\%)\end{array}$ \\
\hline 1 & Income & 73,47 \\
\hline 2 & Savings & 69,44 \\
\hline 3 & Assistance / Subsidies & 78,93 \\
\hline 4 & Individual Credit & 70,13 \\
\hline 5 & $\begin{array}{l}\text { Credit from Credit } \\
\text { Institutions }\end{array}$ & 82,13 \\
\hline 6 & Remittances & 57,87 \\
\hline \multicolumn{2}{|c|}{ Total average } & 80,58 \\
\hline
\end{tabular}

Source: Primary data analyzed, 2020

Table 5 shows that social capital has an average index of $70.02 \%$, with a good interpretation. The highest indicator is the credit to credit institutions at $82.13 \%$. Respondents took loans to start farming activities such as purchasing seeds, fertilizers, and other production facilities. This is done because there are limitations on the savings they have (explained by the index score in this study which gets the second-lowest score after remittances). In terms of income, respondents who are farmers experience fluctuations due to the seasonal nature of agricultural commodities. In addition, farming productivity is not as good as before the eruption of Mount Kelud because the material from the eruption, which still covers the land, has become a problem in itself so that the allocation of household consumption expenditures of respondents is almost or even cannot be fulfilled by farming activities alone.

\section{e. Physical Capital}

Physical capital is basic facilities and other infrastructure built to support community livelihoods. The facilities and infrastructure referred to include all the development of a physical environment that supports the community to carry out productive activities (DFID, 2000). 
Table 6. Score Index for Physical Capital Indicators

\begin{tabular}{|c|l|c|}
\hline No & \multicolumn{1}{|c|}{ Indicator } & $\begin{array}{c}\text { Score } \\
\operatorname{Index}(\%)\end{array}$ \\
\hline 1 & Accessibility & 82,13 \\
\hline 2 & Facilities & 76,80 \\
\hline 3 & Infrastructure & 78,60 \\
\hline 4 & Work equipment & 76,80 \\
\hline \multicolumn{2}{|c|}{ Total average } & 78,21 \\
\hline
\end{tabular}

Source: Primary data analyzed, 2020

From table 6 above, the majority of respondents in the study area already have good accessibility to transportation, information and communication technology. The accessibility indicator is the indicator with the highest index of $82.13 \%$ with very good interpretation. Meanwhile, the agricultural production infrastructure indicator is the indicator with the smallest index, which is $78.60 \%$.

\section{Analysis of Farmer Livelihood Strategies}

Scoones (1998) and DFID (2000) describe livelihood strategy as a series of activities to carefully organize or plan an effort to respond to any changes that occur in life in order to achieve the desired goals or objectives. This study uses a typology of Livelihood strategies White (, 1991). The livelihood strategies of the respondents in the study area were categorized into a survival strategy, a consolidation strategy, and an accumulation strategy.

Table 7. Classification of Respondents Livelihood Strategy Index

\begin{tabular}{|c|l|c|}
\hline No & \multicolumn{1}{|c|}{ Livelihood Strategy } & $\begin{array}{c}\text { Score } \\
\text { Index }(\%)\end{array}$ \\
\hline 1 & Survival Strategy & 49,18 \\
\hline 2 & Consolidation Strategy & 52,80 \\
\hline 3 & Accumulation Strategy & 69,47 \\
\hline
\end{tabular}

Source: Primary data analyzed, 2020

Based on table 7 above, information is obtained that farmer households in the study area have various livelihood strategies. Cumulatively, the accumulation strategy is the highest with a score index percentage of $69.47 \%$, then the consolidation strategy is $52.8 \%$, and the last one is the survival strategy at $49.18 \%$.
Chambers \& Conway (1992) defines sustainable livelihoods as a livelihood that includes abilities, skills, assets (savings, resources, claims and access) and activities needed in order to overcome and improve oneself from pressure and disaster, maintain or improve skills. And assets, and provide sustainable livelihoods for the next generation and that contribute to other livelihoods at local and global levels in the short and long term.

The accumulation strategy with the highest index score was carried out by respondents in the study area by opening other businesses such as food stalls, raising dairy cows, and expanding their businesses through credit loans. A total of $5.33 \%$ of respondents opened stalls that sell daily necessities and gasoline. Then $96 \%$ of respondents are also breeders who raise dairy cows to produce fresh milk, which is then sold to KUD Sumber Makmur. The accumulation strategy is a new strategic option for respondent households that already have assets and can also meet their needs. The assets controlled are not only used to meet their needs but can be allocated to raise capital (investment) in the long term to further increase their income.

The strategy with the next highest index is the consolidation strategy, which is $52.80 \%$. Respondents with a consolidation strategy are middle-class households who have finished with fulfilling their daily needs. This household group prioritizes security as well as income stability from the management of their livelihood resources (Scoones, 1998). Respondents in the research area implemented a consolidation strategy through the use of yards for farming and raising livestock, making loans/credits, utilizing networks as well as optimizing household resources such as labour. Given that this consolidation strategy is an intermediate strategy, respondents who use this strategy are faced with several options. If the gradual implementation is successful, there will be opportunities to apply the accumulation strategy, while if it does not work or a complex threat/vulnerability arises, the household can fall back into the survival strategy group.

The last type of strategy is a survival strategy. The analysis showed that the survival strategy had the smallest index value of $49.18 \%$. The survival strategy is a strategy applied by respondents who 
have limited mastery of livelihood assets. Sulistyastuti and Faturochman (2000) state that the characteristics of a survival strategy are household persistence to survive through various livelihood activities, but the results are only a few.

Respondents in the research area implemented a survival strategy by making savings through limiting/reducing household consumption for food consumption and purchasing consumptive goods that could cause welfare problems. The limitation of food consumption is carried out by reducing the frequency of daily meals and also limiting the diversity of food types (side dishes) consumed. Apart from that, the purchase of other consumptive items such as clothing, electronic equipment, and jewellery is also subject to restrictions. And finally, respondents are also very dependent on government assistance programs such as the Family Hope Program (PKH) and also Non-Cash Food Assistance (BPNT) to ensure their survival is good.

Farm households in the research area consciously and deliberately carry out various production activities to increase their source of income in order to strengthen their livelihood systems. Respondents are dryland farmers who rely on rainfall for irrigation. The agricultural pattern used is polyculture with an intercropping system. The agricultural commodities cultivated are also diverse, ranging from secondary crops such as corn, horticultural crops such as tomatoes, chillies, mustard greens, onions, cabbage and so on. Apart from being farmers, respondents also raise dairy cattle to ensure their livelihoods are sustainable during the dry season or during the passive period after leaving the land. One side job he is also involved in is as a sand mason or truck driver when there is a request. In implementing their livelihood strategies, farmer households will be limited by control of livelihood assets, availability of time, and also manpower.

\section{CONCLUSION}

Based on the results of the analysis and discussion, the following conclusions can be drawn:

a. Livelihood assets controlled by farmers in Pandansari Village have various score indexes, namely: the social capital of $80.58 \%$, physical capital of $78.21 \%$, the human capital of $75.96 \%$, the financial capital of $70.02 \%$, and natural capital of $70.00 \%$. Social capital is an asset with a very good interpretation because, as a rural community, social culture is still held firmly by respondents. Meanwhile, natural capital is the most vulnerable asset due to the remaining material from the eruption, which still covers the land for farming.

b. The livelihood strategies applied by farmers in Pandansari Village are determined by mastery of livelihood assets, availability of time and labour. The strategy with the strongest index was the accumulation strategy of $69.47 \%$, then the consolidation strategy of $52.80 \%$ and the last one was the survival strategy of $49.18 \%$.

\section{REFERENCES}

Badan Litbang Pertanian - Kementrian Pertanian. (2015). Kajian Pengembangan Pertanian Pasca Erupsi Gunung Kelud. Badan Litbang Pertanian - Kementrian Pertanian.

Badan Nasional Penanggulangan Bencana. (2014). Rencana Nasional Penanggulangan Bencana 2010-2014. Jakarta: Badan Nasional Penanggulangan Bencana.

Badan Pusat Statistik. (2019). Keadaan Angkatan Kerja di Indonesia Agustus 2019 (S. S. Ketenagakerjaan, Ed.). Jakarta: Badan Pusat Statistik Republik Indonesia.

Chambers, R., \& Conway, G. R. (1992). Sustainable rural livelihoods: practical concepts for the 21 st century. IDS Discussion Paper, 296.

Dahlgreen, R. A., Saigusa, M., \& Ugolini, F. C. (2004). The Nature, Properties, and Management of Volcanic Soils. In Advances in Agronomy (First Edit). California: Academic Press.

DFID. (2000). Sustainable Livelihoods Guidance Sheets. Retrieved from http://www.livelihoods.org/info/info_guida ncesheets.html

Efendi, T. (2006). Perencanaan Pembangunan Daerah Bidang Pertanian (Studi tentang Perencanaan Pembangunan Pertanian Tanaman Pangan diKabupaten Pemalang, Propinsi Jawa Tengah). Program Pascasarjana UB, Malang.

Eswaran, H., Berg, E. V. A. N. D. E. N., \& Reich, P. (1993). Organic Carbon in Soils of The Worlds. Soil Science Society of America 
Journal, 192-194.

Pospěch, P., \& Spěšná, D. (2011). What is the importance of social capital in Czech agriculture? An analysis of selected components. Agricultural Economics, 57(6), 279-287. https://doi.org/10.17221/163/2010agricecon

Rahayu, R., Ariyanto, D. P., Komariah, K., Hartati, S., Syamsiyah, J., \& Dewi, W. S. (2014). Dampak Erupsi Gunung Merapi Terhadap Lahan Dan Upaya-Upaya Pemulihannya. Caraka Tani: Journal of Sustainable Agriculture, 29(1), 61. https://doi.org/10.20961/carakatani.v29i1.1 3320

Shoji, S., \& Takahashi, T. (2002). Environmental and agricultural significance of volcanic ash soils. Global Environmental ResearchEnglish Edition, 6(2), 113-135. Retrieved from http://www.airies.or.jp/attach.php/6a6f757 26e616c5f30362d32656e67/save/0/0/06_212.pdf

Singarimbun, \& Effendi. (2006). Metode Penelitian Survai (Revisi ked). Jakarta Barat: Pustaka LP3ES Indonesia.
Scoones, I. (1998). Sustainable Rural Livelihoods a Framework for Analysis - IDS Working Paper 72.

Solimun dkk. (2018). Metode Statistika Multivariat Pemodelan Persamaan Struktural (SEM) Pendekatan WarpPLS (Keempat). Malang: UB Press.

Sugiyono. (2011). Metode Penelitian Kuantitatif, Kualitatif dan R\&D. Bandung: Alfabeta.

Sulistyastuti, D. R., \& Faturochman, F. (2016). Strategi Bertahan Hidup Di Tiga Wilayah. Populasi, 11(1), 59-82. https://doi.org/10.22146/jp.12332

Wijayanto, H., Affandi, A., \& Soemarno, S. (2019). Pengaruh Livelihood Asset terhadap Livelihood Strategies Masyarakat Tepi Hutan di UB Forest Desa Tawangargo Kecamatan Karangploso Kabupaten Malang. Habitat, 30(2), 54-61. https://doi.org/10.21776/ub.habitat.2019.03 0.2 .7

White, B. (1991). Economic Diversification and Agrarian Change in Java: 1900-1990. In The Shadow of Agriculture: Non-Farm Activities in The Javanese Economy: Past and Present, pp. 41-69. 
This page is intentionally left blank 